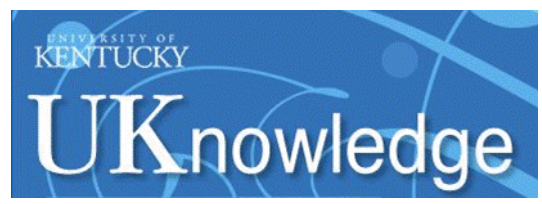

University of Kentucky

UKnowledge

Summer 6-1-2019

\title{
Measuring Up: A Case for Redrawing the System Boundaries of Sustainability at the University of Kentucky
}

\author{
Brent Sturlaugson \\ University of Kentucky, brent.sturlaugson@uky.edu \\ Rebekah Radtke \\ University of Kentucky, rebekah.radtke@uky.edu \\ Anita Lee-Post \\ University of Kentucky, Anita.Lee-Post@uky.edu
}

Follow this and additional works at: https://uknowledge.uky.edu/architect_facpub

Part of the Interior Architecture Commons, Interior Design Commons, and the Sustainability Commons

Right click to open a feedback form in a new tab to let us know how this document benefits you.

\section{Repository Citation}

Sturlaugson, Brent; Radtke, Rebekah; and Lee-Post, Anita, "Measuring Up: A Case for Redrawing the System Boundaries of Sustainability at the University of Kentucky" (2019). Architecture Faculty Publications. 6.

https://uknowledge.uky.edu/architect_facpub/6

This Article is brought to you for free and open access by the Architecture at UKnowledge. It has been accepted for inclusion in Architecture Faculty Publications by an authorized administrator of UKnowledge. For more information, please contact UKnowledge@lsv.uky.edu. 
Measuring Up: A Case for Redrawing the System Boundaries of Sustainability at the University of Kentucky

Digital Object Identifier (DOI)

https://doi.org/10.3992/1943-4618.14.3.159

Notes/Citation Information

Published in Journal of Green Building, v. 14, issue 3.

Journal of Green Building has granted the permission for posting the article here. 


\title{
MEASURING UP: A CASE FOR REDRAWING THE SYSTEM BOUNDARIES OF SUSTAINABILITY AT THE UNIVERSITY OF KENTUCKY
}

\author{
Brent Sturlaugson, ${ }^{1}$ Rebekah Radtke, ${ }^{2}$ and Anita Lee-Post ${ }^{3}$
}

\begin{abstract}
The primary goal of this paper is to examine the role that sustainability assessment and reporting plays in creating a sustainable campus for academic excellence. A prototype sustainability assessment and reporting system is developed for triple bottom line impact analysis of the built environment of the newly expanded and renovated Gatton College of Business and Economics at the University of Kentucky. The prototype system utilizes a toolkit to collect environmental, social, and economic data of the building's built environment for sustainable design performance analyses. The system also employs a comprehensive set of sustainability metrics to measure and report the building's triple bottom line impacts on academic success. In sum, our study succeeds in (1) expanding the definition and evaluation of campus buildings' sustainability to include environmental, social, and economic factors, (2) providing campus stakeholders with a toolkit for assessing the sustainability of campus buildings, and (3) creating a comprehensive sustainability metric for benchmarking and tracking campus buildings' triple bottom line impacts on academic success.
\end{abstract}

\section{KEYWORDS}

sustainable campus, sustainability assessment and reporting, sustainability metric, triple bottom line impacts, academic success

\section{INTRODUCTION}

To define any object of measurement, one must first identify the boundary condition of the system under consideration. Simple tasks such as measuring the height or weight of a human body present a clear boundary, but for projects that seek to examine sustainability in architecture, a concept burdened by enormous complexities, the identification of system boundaries becomes acutely problematic (Simonen et al., 2017). Efforts in the design professions to define the system boundaries of sustainable processes or products abound, yet each attempt fails to account for the myriad effects set in motion by activities in the design professions. Some efforts acknowledge the partiality of their accounts, but others make impossible claims of

1. School of Architecture, University of Kentucky,Lexington, Kentucky, 40506, United States, email: brent.sturlaugson@uky.edu 2. School of Interiors, University of Kentucky, Lexington, Kentucky, 40506, United States, email: rebekah.radtke@uky.edu

3. Gatton College of Business and Economics, University of Kentucky, Lexington, Kentucky, 40506, United States, email: anita.lee-post@ uky.edu 
comprehensiveness. After all, sustainability in architecture can only ever be a pursuit, which is not to discredit the topic, especially as contemporary indicators increasingly show the urgency of the pursuit. Indeed, sustainability remains among the most pressing issues concerning architecture and design. How, then, can the design professions better account for these myriad effects? What technologies might enable a more thorough understanding of sustainability in design? How are the system boundaries of sustainability in architecture defined?

The intellectual history of sustainability is vast, and it is not the purpose of this paper to survey its contours (Brandt et al., 2013). Rather, this paper questions the system boundaries of sustainability in architecture by drawing on ideas outlined by Gregory Bateson in his essays collected in Steps to an Ecology of Mind, particularly the lecture from 1970, "Form, Substance, Difference." Questioning the system boundaries of a blind man as he negotiates his surroundings with a stick, Bateson asks, "Does it start halfway up the stick? Does it start at the tip of the stick?" (Bateson, 1972, pp. 459). The problem of delineating system boundaries, for Bateson, is one of accounting for difference. In other words, he seeks to map "differences that make a difference" in order to more precisely identify systems.

For Bateson, the system boundaries extend beyond the obvious, "you will need the street, the stick, the man; the street, the stick, and so on, round and round" (Bateson, 1972, pp. 459). Several years before Bateson's lecture, similar ideas about system boundaries were in circulation in architectural discourse, most notably in Christopher Alexander's 1965 article, "A City Is Not a Tree," in The Architectural Forum. Describing what he calls a "unit of the city," Alexander notes the different components of a ubiquitous situation at the corner of Hearst and Euclid in Berkeley, where "there is a drug store, and outside the drug store a traffic light. In the entrance to the drug store there is a newsrack where the day's papers are displayed ... This effect makes the newsrack and the traffic light interdependent; the newsrack, the newspapers on it, the money going from people's pockets to the dime slot, the people who stop at the light and read papers, the traffic light, the electric impulses which make the lights change, and the sidewalk which the people stand on form a system - they all work together" (Alexander, 1965). Like Bateson, Alexander expands the system boundaries by accounting for less obvious effects (Figure 1).

Following these theorists, this paper questions the system boundaries of sustainable design research. Using a recent case study as evidence, it seeks to redraw the system boundaries of sustainability by asking the following questions. Does it start at the building envelope? Does it start at the social spaces that surround the building envelope? Does it start with the relationships that form as a result of the building program?

This paper argues three points. First, to better understand sustainability in design, research must engage other disciplines. As a profession characterized by its relationships with other fields of expertise, a similar dedication to multi-disciplinarity must accompany sustainability research in architecture. Second, to effectively measure sustainability in design, technology must be understood in the broadest possible terms. In addition to embracing the latest innovations in hardware and software engineering, technology must also be understood to include the methods by which these hardware and software are deployed. Third, to promote sustainability in design, the methods by which sustainability is measured must themselves be sustainable. Rather than designing a research framework that relies on interpretation by field-specific specialists, a more sustainable method must democratize the ways in which these measurements are collected and then disseminated (Slaper and Hall, 2011). In making these arguments, this paper draws on research from a study led by a multidisciplinary team that examined the social, environmental, and economic sustainability (i.e., the triple bottom line) of a recently renovated and expanded 
FIGURE 1. Diagram of sustainability research methods, after Christopher Alexander.
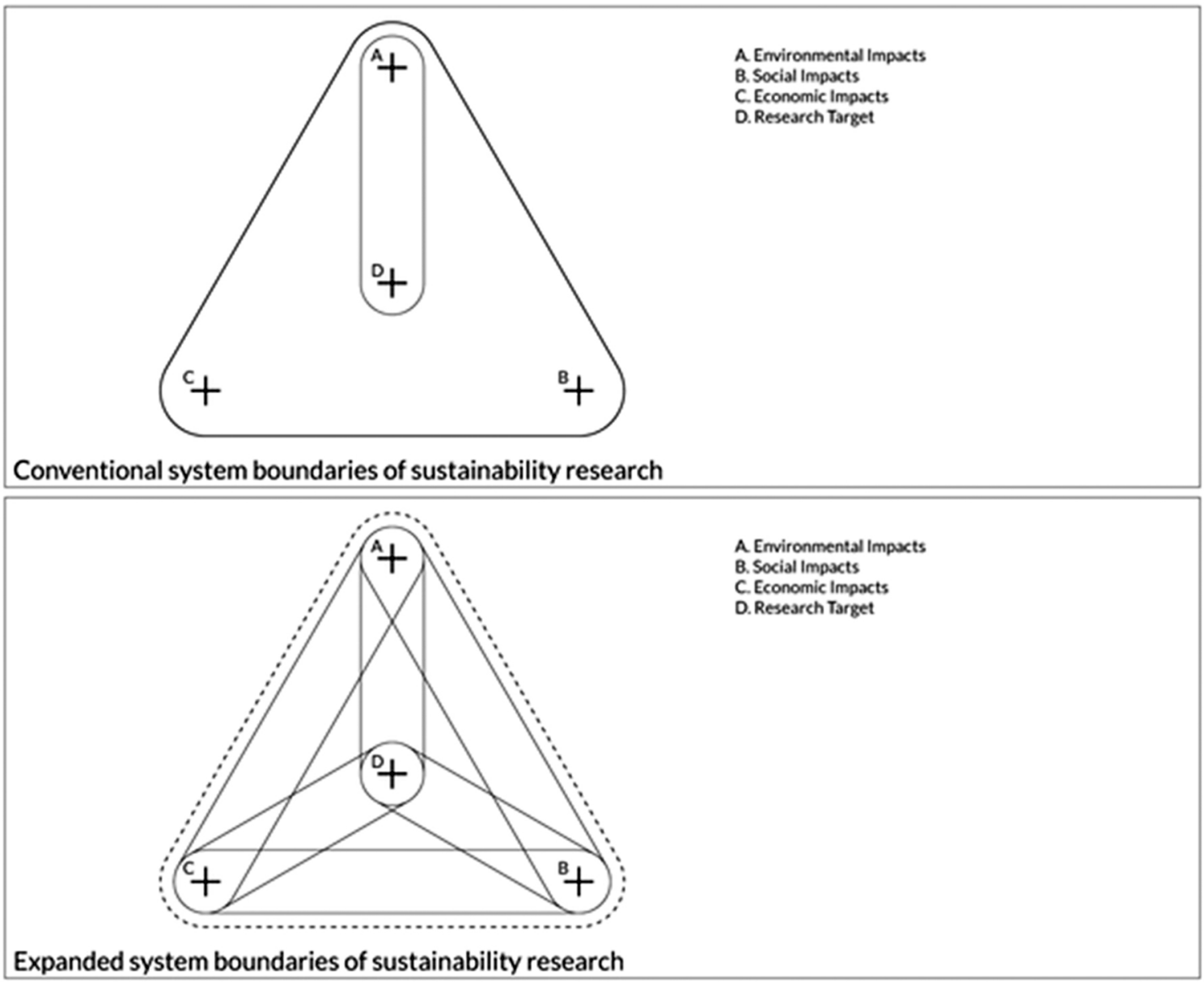

academic building. The study sought to broaden the scope of sustainability discourse in architecture and design by reimagining the terms by which sustainability is measured.

\section{STUDY BACKGROUND AND RESEARCH FRAMEWORK}

The study centers on the Gatton College of Business and Economics that offers undergraduate and graduate degree programs for 4,000 students (Figure 2a, 2b).

At the center of campus occupying 1.48 acres, the building is a landmark on the university campus. The original building was constructed in 1963 with a classroom addition in 1991, and in 2005 a decision was made to commission a new building. The new building was planned for construction on the northern edge of campus on an existing parking lot. A series of financial crises, however, kept the project from proceeding, and in 2009 the plan was abandoned. In 2013, the planning team decided to renovate the existing building for a second time as a privately financed 65-million dollar project. Expanding from 140,000 to 225,000 square feet, the building holds 20 classrooms, a large lecture hall, 42 study rooms, a new dining facility, faculty offices, and social zones designed to encourage collaboration. The building boasts 
FIGURE 2A. Exterior of the renovated and expanded Gatton College of Business and Economics at the University of Kentucky.

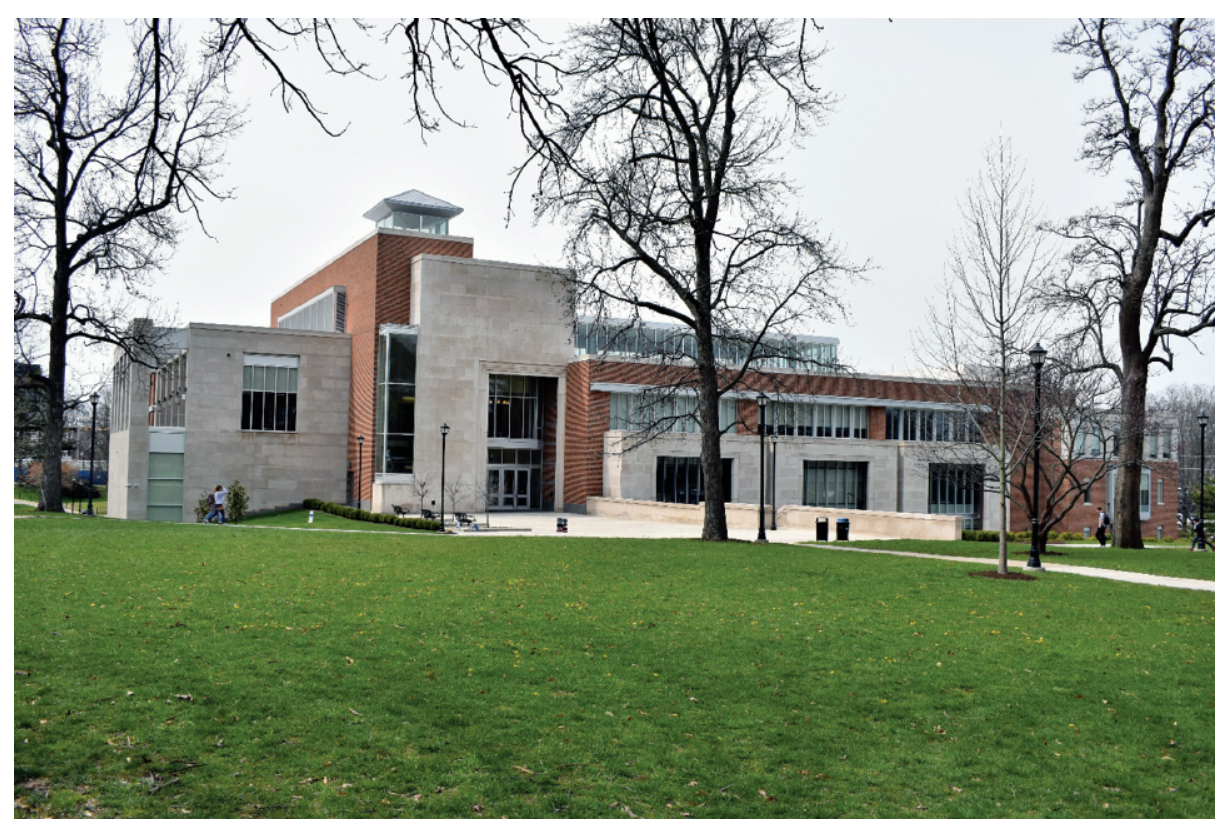

FIGURE 2B. Semi-public space designed for student collaboration in the Gatton College of Business and Economics.

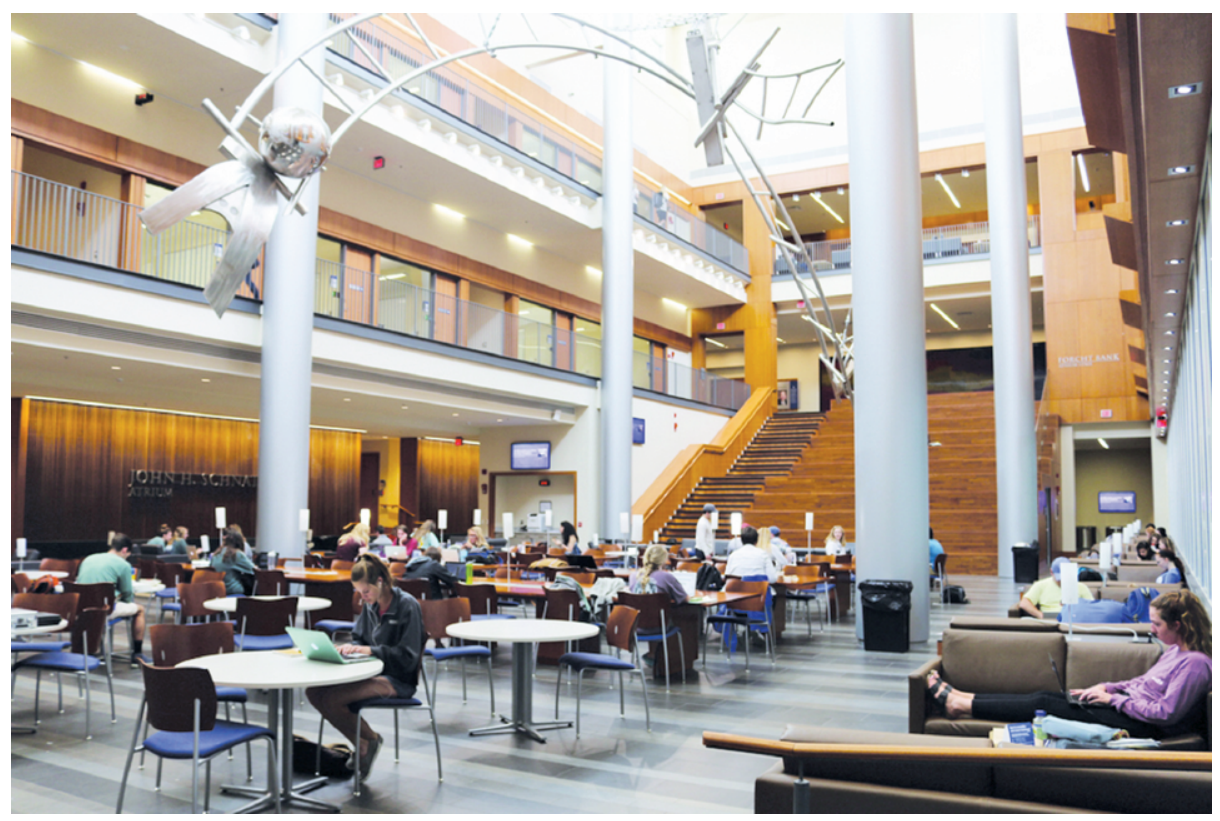


natural daylighting, occupancy sensors, integrated technology for space management, and locally sourced materials, and in 2016 it earned LEED Gold certification (Denzer and Hedges, 2011).

For this paper, the newly expanded building provided the case study for questioning the system boundaries of sustainability in architecture. The research team, consisting of faculty and students from architecture, interiors, economics, business and statistics at the University of Kentucky developed a prototype sustainability assessment and reporting system. To measure the sustainability according to the design, construction, and patterns of use, the research methods included document reviews and analysis, interviews, surveys, focus groups, direct observation, and building performance data gathering. The data collected from these research methods was analyzed against the stated sustainability goals of the project, including energy and resource conservation, landscape and ecology integration, mobility and accessibility improvement, and community development and advancement. Using statistical models, the team then evaluated the relationship between these sustainability goals and several indicators of academic success.

The principle outcome of this study was a metric that considered environmental, social, and economic factors in the sustainability assessment of the built environment. Other outcomes included an increased awareness among campus stakeholders of the multidimensional aspects of sustainability, inclusive of environmental, social, and economic variables, as well as a better understanding of features in the built environment that contribute to academic success, utilizing the campus as a living laboratory for design research.

\section{Redrawing The System Boundaries Of Sustainability}

The primary goal of this paper is to examine the role that sustainability assessment and reporting plays in creating a sustainable campus for academic excellence. To achieve this goal, the system boundaries of sustainability is redrawn to include environmental, social, and economic factors in the definition and evaluation of the built environment of campus buildings. The expanded definition of sustainability further guides the investigation of the extent to which a sustainable built environment contributes to academic success.

We adopted a case study approach to pilot test a prototype sustainability assessment and reporting system developed for triple bottom line impact analysis of the built environment of a newly expanded and renovated campus building. The system also employs a comprehensive set of sustainability metrics to measure, track, report and benchmark the building's triple bottom line impacts on academic success. The prototype system utilizes a toolkit to collect environmental, social and economic data of the building's built environment for sustainable design performance analyses. Three types of instruments comprised the toolkit used to collect data on the environmental, social, and economic sustainability of the building. Environmental tools, such as sound intensity meters, luminance meters, and temperature data loggers, were used to collect data on air quality, lighting, temperature, relative humidity, and other factors. Social tools, such as validated survey instruments, protocols for interviews and direct observations, and focus group discussion questions, were used to gain a better understanding of campus stakeholders' perspectives on sustainable design and its contributions to academic success. Economic tools, such as statistical models, used operational data from the university's institutional research and advanced analytics server and other sources to conduct economic performance analyses of both environmental and social sustainability features. The environmental, social, and economic tools were catalogued and compiled in a lending library to promote future research using similar methods. 
Using the toolkit outlined above, the team collected data from the semi-public spaces in the building to assess the multidimensional sustainability of the newly designed space. This process sought to develop a system for analyzing the effects of certain architectural design decisions on academic success, defined here as undergraduate retention rate, faculty research productivity, and campus community engagement, among others. Understanding these effects, in turn, would allow stakeholders to make informed choices in the design process of future projects geared toward sustainability and its impact on future campus planning and infrastructure.

\section{Environmental Sustainability}

In this study, environmental sustainability consists of those factors that contribute directly to human comfort. Human comfort, however, is a subjective matter, which makes data collection that seeks objectivity a troublesome affair (Rupp et al., 2015). To address the subjectivity of data concerning human comfort, the research team produced a series of visualizations, distinct from the typical graph format, that help communicate the qualities of this data (Figure 3).

Produced using data collected with equipment from the tool library in combination with Grasshopper 3D and Rhinoceros, these methods contributed to the sustainability of the research itself. In addition to the reusability of the data collection equipment, the visualization scripts are also reusable. This enables future research to draw on methods developed for this project in ways that lower the threshold of accessibility, thereby establishing a more sustainable approach to design research.

The study targeted three categories of environmental quality: air, light, and sound (Table 1). The air qualities under investigation were dry bulb temperature, wet bulb temperature, surface temperature, relative humidity, carbon dioxide levels, and air velocity.

To measure these air qualities, the team used handheld wind meters, deployable data loggers, infrared temperature meters, and air quality monitors. The light qualities under investigation were luminance and illuminance, each of which were measured using handheld meters. The sound qualities under investigation were intensity and periodicity, and were also measured with handheld meters (Figure 4).

The resulting data was combined with other measures and used to produce an economic model that targeted academic success. Seeking to promote the sustainability of the research process itself, tutorials describing the methods for using this equipment were produced and archived on the project website. Additionally, the toolkit and its tutorials help furthering the learning objectives of courses in Architecture and Interior Design. In particular, fourteen students in ARC253 (Design Studio III) conducted a site analysis with building performance equipment to understand the environmental conditions at different locations along Short Street in Lexington, Kentucky. Sixty students in ARC 332 (Environmental Controls I) learned how to use the toolkit in architectural research applications.

\section{Social Sustainability}

This case study also explored how to connect quantitative and qualitative data to create a more thorough assessment of the building's social impact. Social sustainability can be broadly defined to include processes, societies, infrastructures, and amenities that contribute to livable communities for humanity now and in the future (WACOSS, 2018; Dillard et al., 2009; Coates, 2003). However, measurements of building performance in post occupancy evaluation typically focus on the environmental aspects of sustainability through LEED certification and other performance metrics, which often exclude social indicators. Other metrics, such as WELL, emphasize 
FIGURE 3. Sample visualization of environmental sustainability data, showing readouts of humidity levels, a Grasshopper definition, and a Rhinoceros model of humidity levels in the space at each measured interval.
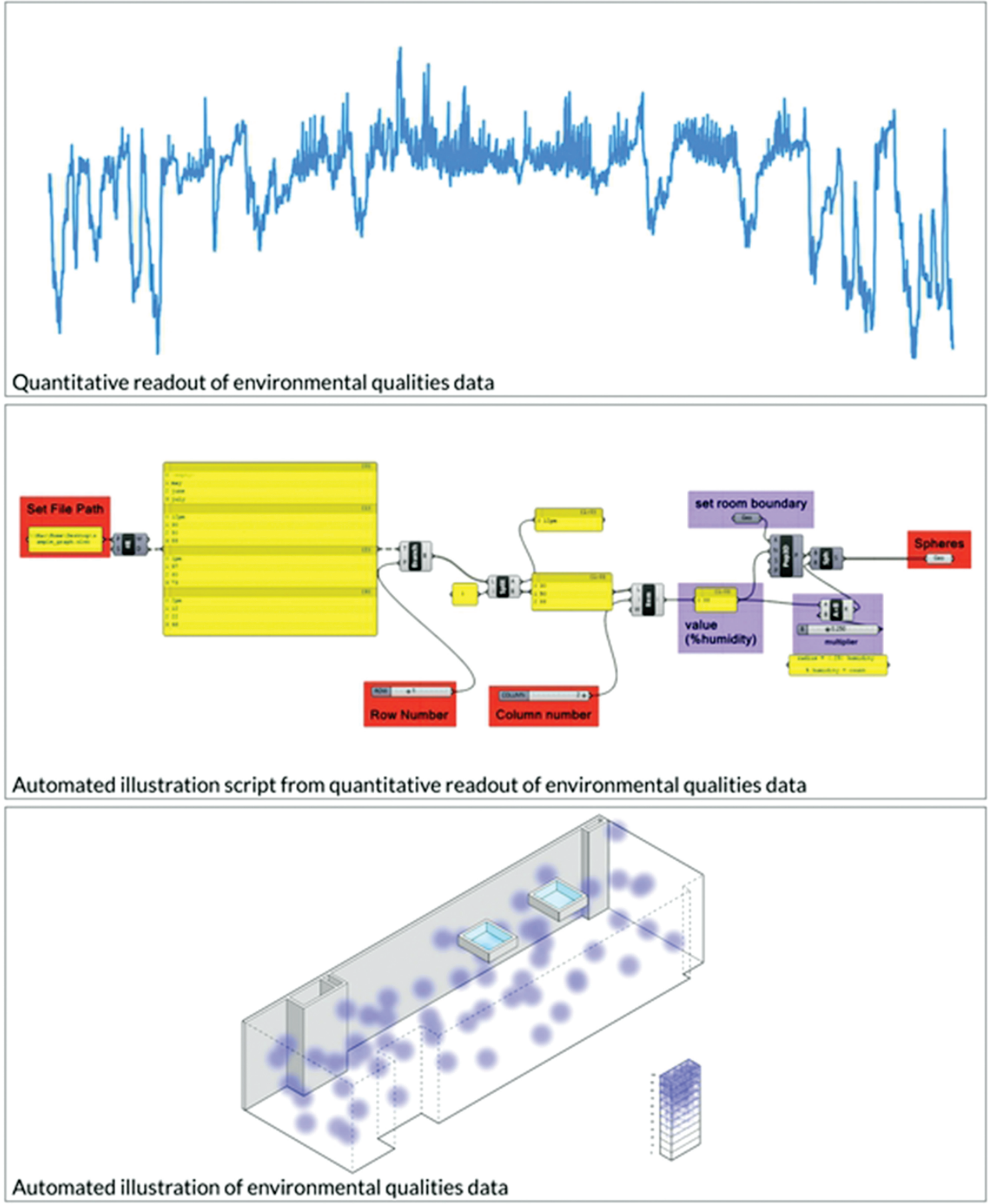


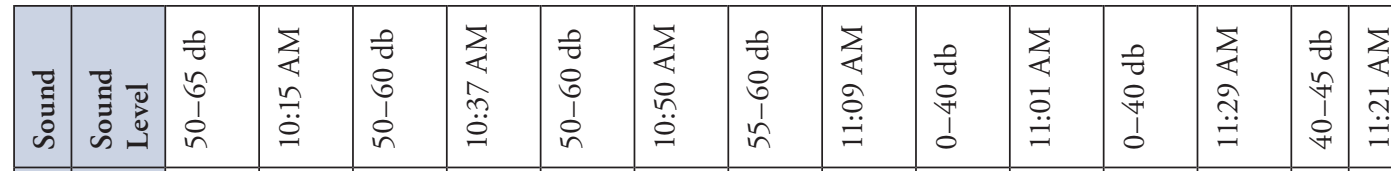

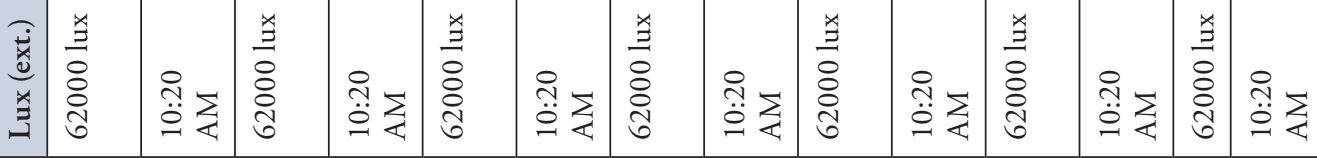

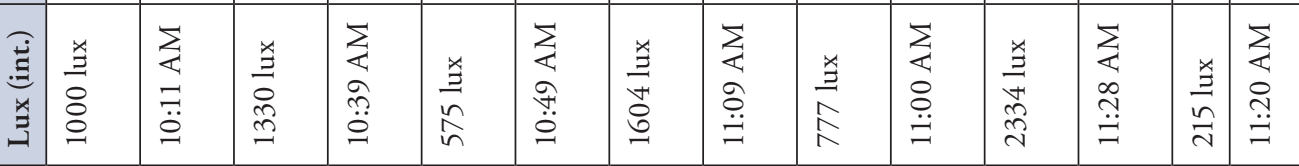

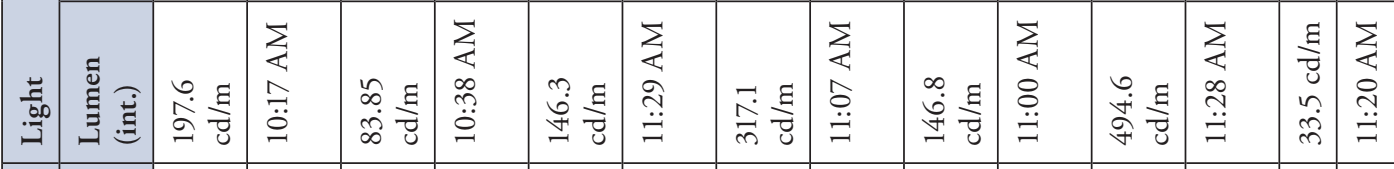

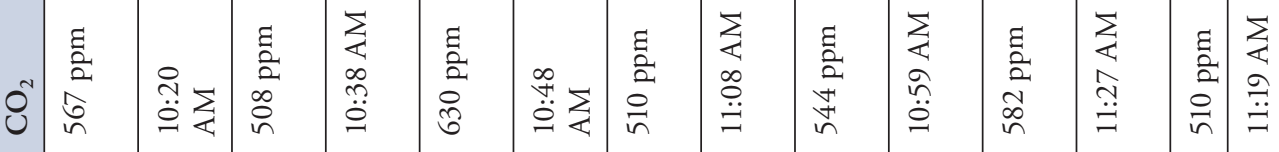

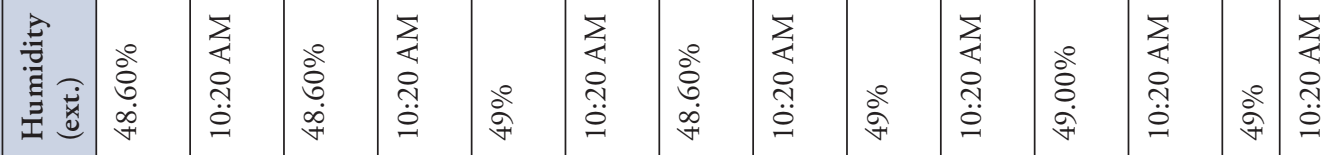

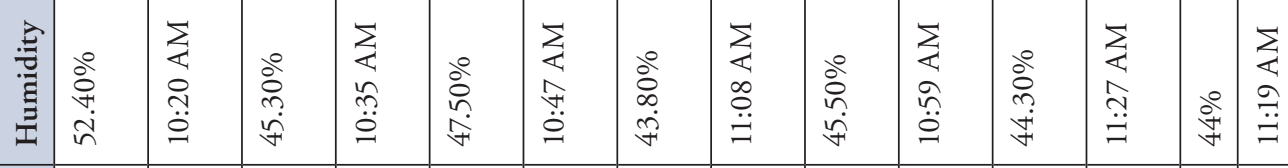

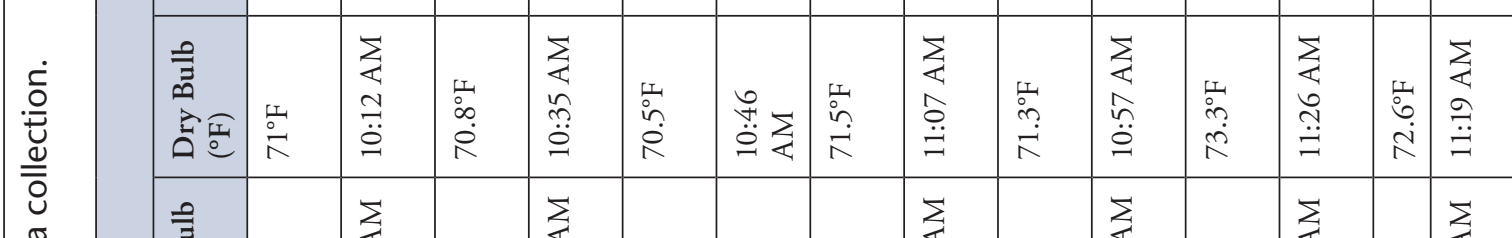

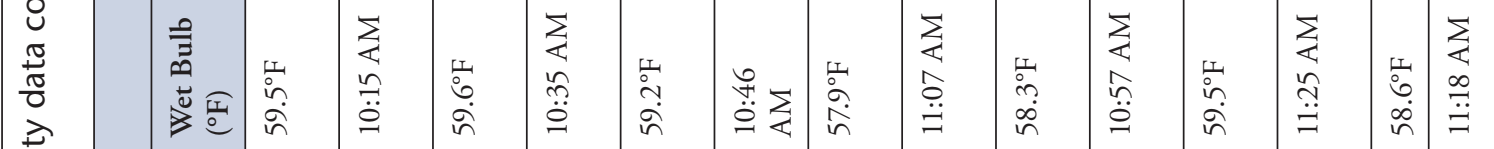

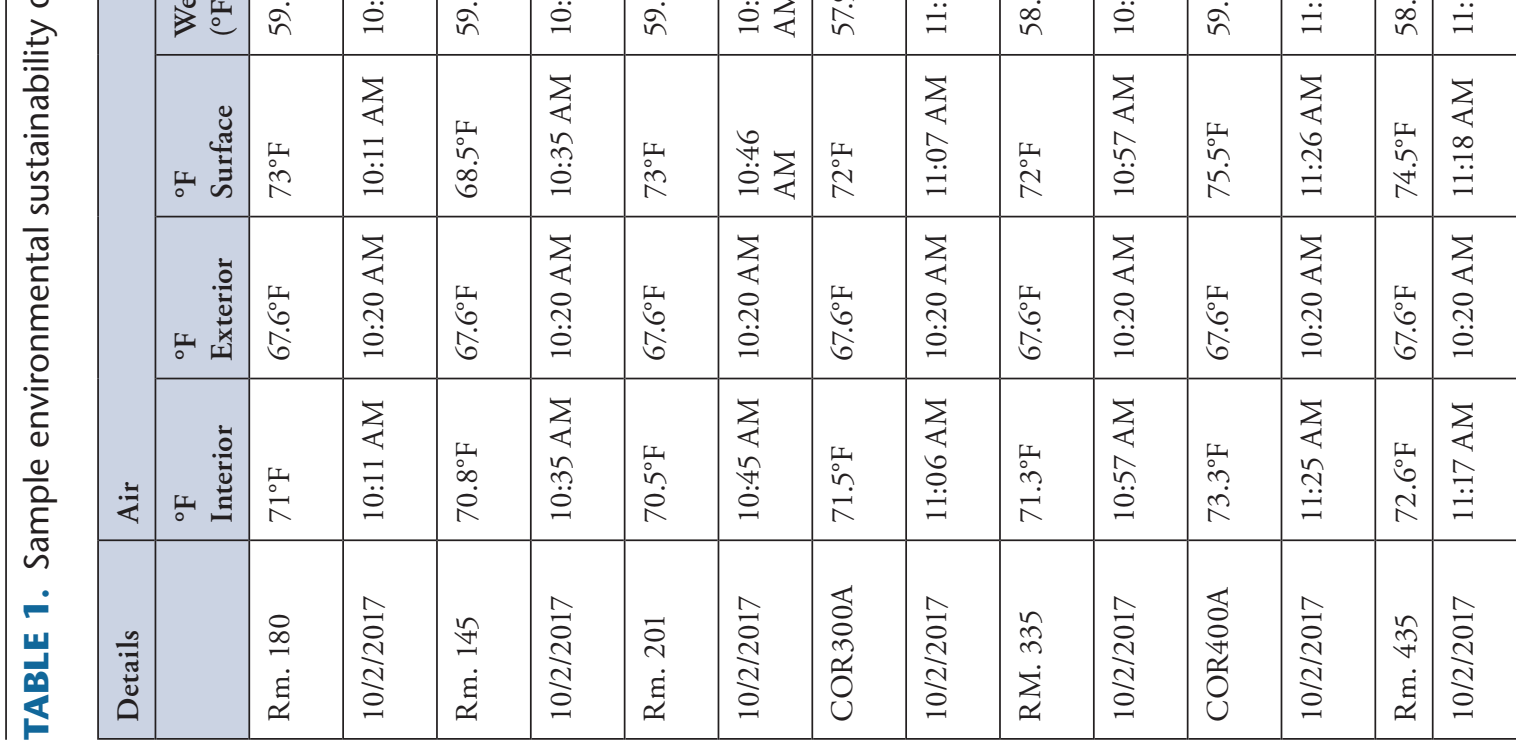


FIGURE 4. Environmental sustainability data collection process.

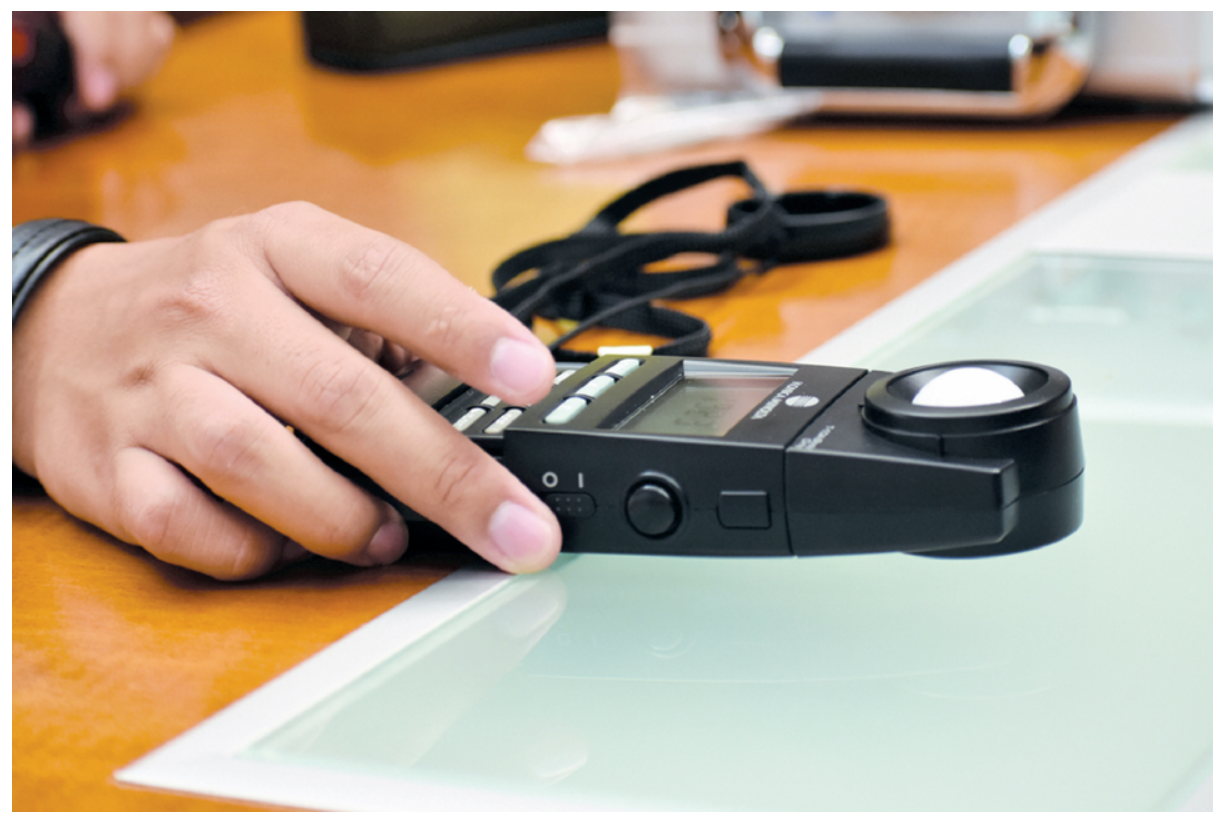

the experience of the environment and its impact on the health of the occupants which reflect a more inclusive model (Gonchar, 2015). Striving for a more holistic approach, the social aspect of this study sought to provide a deeper understanding of the connection between the building design and its impact on users. Understanding how daylighting and building performance affect student collaboration and academic success, in this case, was critical to the sustainable development of the campus environment. In this study, considerations of social sustainability expanded the definition of traditional sustainable design principles of site selection, energy, locally sourced and environmentally conscious products, water conservation, and air quality to include well-being, user satisfaction, and student success. The social sustainability of this case study specifically focused on user experience in the semi-public zones with a focus on collaboration and how it can contribute to student success.

The team of faculty and undergraduate researchers collected data using a mixed methods approach over the course of one year. The team explored various means of collecting data by distributing a questionnaire to all faculty, staff, and students within the college, by conducting observations within the space, and by administering a targeted survey to users within the atrium (Figure 5).

Questions explored how the building supports collaboration, studying, and socialization, among other behaviors. Frequency of use and duration of visits with specific spaces were analyzed to understand the user preferences of the building. The in-depth survey tool allowed a deeper understanding in multiple Likert scale questions specific to the environment beyond the standard assessment used in industry standard evaluations (IWBI, 2018; CBE 2018). Please refer to the appendix for a sample questionnaire of the questions asked.

\section{Economic Sustainability}

Economic sustainability, in this study, consists of several factors, including energy conservation, resource utilization, and waste reduction (Sanders and Wood, 2015). Economic tools, 
FIGURE 5. Social sustainability data collection process.

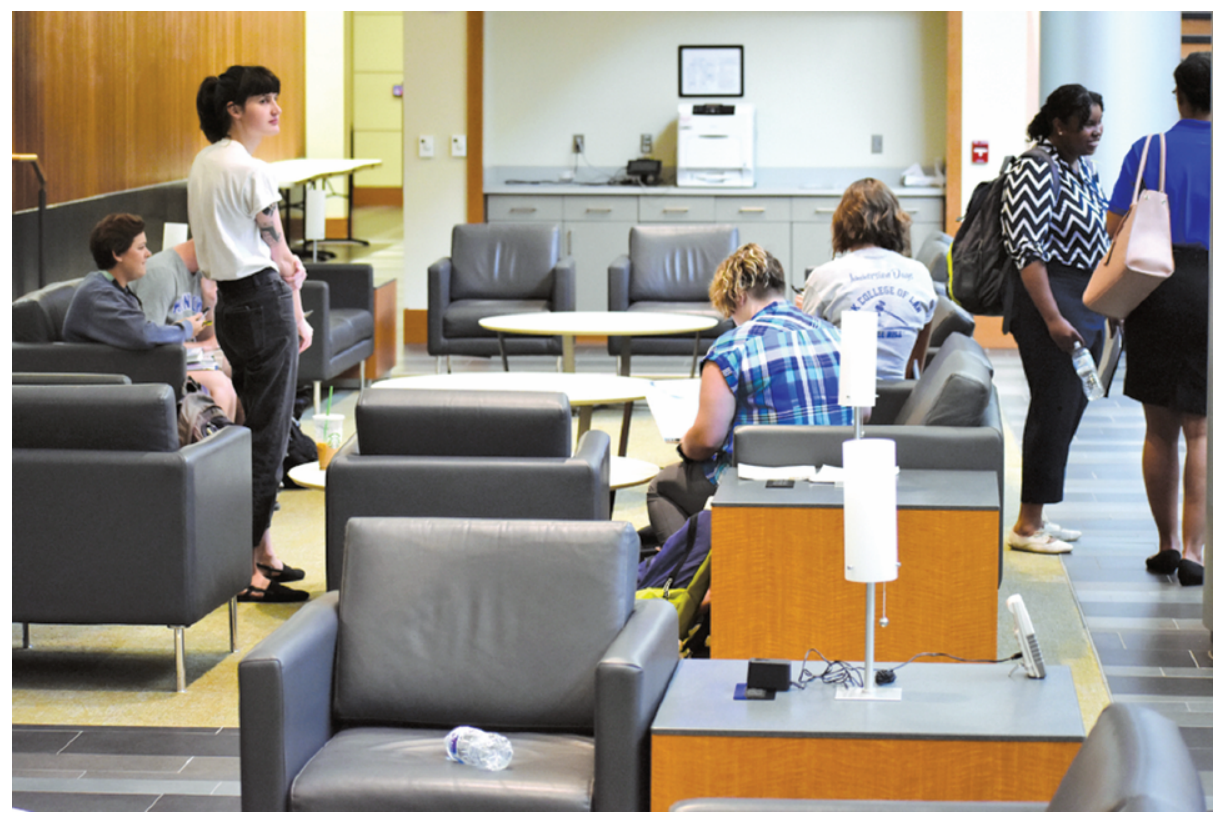

primarily statistical software and models, were used to analyze data on building operations to determine its effects on the triple bottom line. Operational data from 2011 to 2016, including energy, water, and operational costs, were collected from the campus' physical plant, the university's institutional research and advanced analytics server, and an internal college factbook. A before (the average of 2011 to 2013) and after (the actual figure of 2016) comparison of the operational costs was conducted to gauge the economic impacts of the building renovation. The operational data of 2014 to 2015 were excluded in the analysis because the college was moved to a temporary location during the building renovation. As shown in Table 2, the economic impacts of the renovation were largely positive, as evident from a cost saving of $17 \%$ in energy, $11 \%$ in water, and $30 \%$ in operating expenses (Table 2).

\section{A MODEL OF SUSTAINABILITY}

Based on the above definitions and evaluations of the environmental, social, and economic sustainability, the research team developed a model that illustrates the relationship between sustainable design and academic support using both qualitative and quantitative factors (Figure 6).

TABLE 2. A comparison of economic sustainability before and after renovation.

\begin{tabular}{|l|l|l|l|}
\hline Economic Impact & Before & After & $\%$ Change \\
\hline Gross square footage (GSF) & 138,377 & 212,855 & $54 \%$ \\
\hline Energy $(\$ / G S F)$ & $\$ 1.62$ & $\$ 1.35$ & $-17 \%$ \\
\hline Water $(\$ / G S F)$ & $\$ 0.07$ & $\$ 0.06$ & $-11 \%$ \\
\hline Operating expenses $(\$ / G S F)$ & $\$ 33.49$ & $\$ 23.45$ & $-30 \%$ \\
\hline
\end{tabular}


The model was validated empirically with a survey instrument from the students' perspective. The survey was designed to solicit opinions about the extent to which a sustainable built environment offers academic support. The survey was pilot tested to confirm its internal consistency as items related to each of the four model constructs showed a high measure of scale reliability, defined by a Cronbach's alpha of 0.8 and above (Perterson, 1994). The survey was administered to 4,827 undergraduate and graduate students taking classes in the Gatton College of Business and Economics in the fall of 2017. Although the response rate was only $5 \%$, a multiple regression analysis of the 230 respondents' data provided the following results:

1. Each of the three design impacts is significantly correlated with academic support ( $\mathrm{p}$ $<0.01)$.

2. Social design impact has the strongest correlation with academic support ( $\mathrm{r}$ is 0.738 ).

3. The three design impact factors together account for $57.8 \%$ of the variance in academic support (R-square is 0.578 ).

4. Social design impact has the strongest relationship with academic support (beta is 0.61 ).

Besides quantifying the relationship between sustainable design impacts and academic support, the model also provides a basis for the creation of a set of metrics to measure the triple bottom line impacts on academic success. The metrics rely on both subjective survey data and objective measurement data to quantify four factors: environmental impact, social impact, economic impact, and academic impact. Each factor uses multiple indicators to capture its multi-dimensionality, and an indicator may employ sub-indicators to express the desired level of details/granularities. For example, the economic impact metric uses energy costs, water costs, operating expenses, space utilization, and facility operations as its indicators (Table 3).

The energy indicator, meanwhile, can be further categorized into electricity, steam, and chilled water sub-indicators. Likewise, the space utilization indicator is composed of three subindicators: college activities, university activities, and external activities. Similarly, the facility operations indicator has 12 sub-indicators: furniture, furniture arrangement, seating, layout, operating hours, accessibility, aesthetic, utility, maintenance, technology, safety, and mobility (Table 4).

FIGURE 6. A model of environmental, social, and economic sustainability.

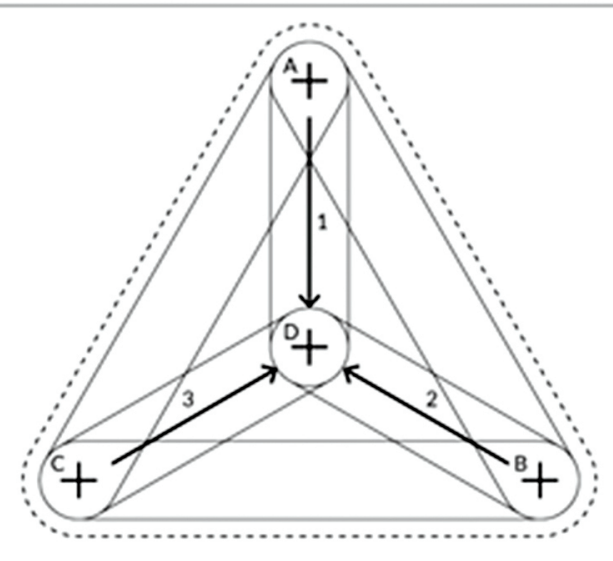

A Ervironmental Impxt

B. Social Impact

C. Operational Impact

D. Academic Support:

1. $r=0.497 \cdot:$ Beta $=0.124$

2. $r=0.738 *$ Beta $=0.61$

3. $r=0.525 ": B e t a=0.137$

"Academic Support $=0.71+0.61 \times$ Social Impact $+0.137 \times$ Operational Impact + $0.124 \times$ Environmental Impact

"Correlation is significant at the 0.01 level

R-square $=0.578$ 
TABLE 3. Economic impact results.

\begin{tabular}{|c|c|c|c|}
\hline Impact & Indicator & Sub-indicator & $2016-2017$ \\
\hline \multirow[t]{9}{*}{ Economic } & \multirow[t]{3}{*}{ Energy } & Electricity & $\$ 129,064.66$ \\
\hline & & Steam & $\$ 71,455.51$ \\
\hline & & Chilled water & $\$ 86,633.05$ \\
\hline & \multicolumn{2}{|l|}{ Water } & $\$ 6,528.10$ \\
\hline & \multicolumn{2}{|l|}{ Sewer } & $\$ 6,736.95$ \\
\hline & \multicolumn{2}{|c|}{ Operating expenses } & $\$ 4,990,398.00$ \\
\hline & \multirow[t]{3}{*}{ Space utilization } & College activities & $91.04 \%$ \\
\hline & & University activities & $8.68 \%$ \\
\hline & & External activities & $0.28 \%$ \\
\hline
\end{tabular}

TABLE 4. Facility operations impact results.

\begin{tabular}{|c|c|c|c|c|c|}
\hline Impact & Indicator & Sub-indicator & Student & Faculty & Staff \\
\hline \multirow[t]{12}{*}{ Economic } & \multirow{12}{*}{$\begin{array}{l}\text { Facility } \\
\text { operations }\end{array}$} & Furniture* & 4.38 & 4.47 & 3.46 \\
\hline & & $\begin{array}{l}\text { Furniture } \\
\text { arrangement* }\end{array}$ & 4.3 & 4.2 & 3.5 \\
\hline & & Seating* & 3.6 & 4.13 & 3.25 \\
\hline & & Layout* & 4.27 & 4.47 & 3.46 \\
\hline & & $\begin{array}{l}\text { Operating } \\
\text { hours* }\end{array}$ & 4.28 & 4.2 & 4.29 \\
\hline & & Accessibility* & 4.57 & 4.47 & 4.42 \\
\hline & & Aesthetic* & 4.59 & 4.8 & 4.33 \\
\hline & & Utility* & 4.41 & 4.27 & 3.92 \\
\hline & & Maintenance* & 4.56 & 4.13 & 3.54 \\
\hline & & Technology* & 4.42 & 4.33 & 4.29 \\
\hline & & Safety* & 4.65 & 4.53 & 4.46 \\
\hline & & Mobility* & 4.54 & 4.67 & 4.5 \\
\hline
\end{tabular}

*Survey Scale, 5 = Strongly Agree, 1 = Strongly Disagree 
TABLE 5. Environmental impact results.

\begin{tabular}{|l|l|l|l|l|l|}
\hline Impact & Indicator & Sub-indicator & Student & Faculty & Staff \\
\hline \multirow{4}{*}{ Environment } & \multirow{2}{*}{$\begin{array}{l}\text { Air and indoor } \\
\text { climate }\end{array}$} & Temperature* & 4.04 & 3.73 & 2.71 \\
\cline { 3 - 6 } & Air Quality* & 4.47 & 4.6 & 4 \\
\cline { 2 - 6 } & Humidity* & 4.38 & 4.47 & 3.96 \\
\cline { 2 - 6 } & Lighting* & 4.53 & 4.33 & 3.63 \\
\cline { 2 - 6 } & Noise* & 3.99 & 3.87 & 3.21 \\
\cline { 2 - 6 } & Safety* & 4.65 & 4.53 & 4.46 \\
\cline { 2 - 6 } & Energy efficiency* & 4.05 & 4.13 & 3.79 \\
\cline { 2 - 5 } & Environmental friendliness* & 4.03 & 4.2 & 4 \\
\hline
\end{tabular}

*Survey Scale, 5 = Strongly Agree, 1 = Strongly Disagree

The remaining metrics are structured in the same fashion. The environmental impact metric is composed of six indicators: air and indoor climate, lighting, noise, safety, energy efficiency, and environmental friendliness (Table 5).

The air and indoor climate indicator have three sub-indicators: temperature, air quality, and humidity. The social impact metric uses four indicators: socialization, sense of community, collaboration, and relaxation (Table 6).

The metric for academic impact is derived from three indicators: student success, faculty success, and staff success (Table 7).

The student success indicator has 13 sub-indicators: undergraduate enrollment, undergraduate degrees awarded, first to second year undergraduate retention rate, percentage of undergraduates with employment after three months of graduation, undergraduate median salary, graduate enrollment, graduate degrees awarded, percentage of full time MBA with employment after 3 months of graduation, full time MBA median salary, learning support, studying support, and innovation support. The faculty success indicator has 12 sub-indicators: student to faculty ratio, teaching quality, teaching awards and recognition, prominent journal publications, research grants submitted, research grants funded, research grants expenditures,

TABLE 6. Social impact results.

\begin{tabular}{|l|l|l|l|l|l|}
\hline Impact & Indicator & Sub-indicator & Student & Faculty & Staff \\
\hline \multirow{4}{*}{ Social } & Socialization* & 4.5 & 4.6 & 4.42 \\
\cline { 2 - 5 } & Sense of community* & 4.31 & 4.4 & 4.04 \\
\cline { 2 - 5 } & Colalboration* & 4.35 & 4.6 & 4.13 \\
\cline { 2 - 5 } & Relaxation* & 3.94 & 4.13 & 3.5 \\
\hline
\end{tabular}

*Survey Scale, 5 = Strongly Agree, 1 = Strongly Disagree 
TABLE 7. Academic impact results.

\begin{tabular}{|c|c|c|c|}
\hline Impact & Indicator & Sub-indicator & 2016-2017 \\
\hline \multirow[t]{29}{*}{ Academic } & \multirow{13}{*}{$\begin{array}{l}\text { Student } \\
\text { success }\end{array}$} & Undergraduate enrollment (Fall cohort) & 3263 \\
\hline & & Undergraduate degrees awarded & 744 \\
\hline & & First to second year undergraduate retention rate (Fall cohort) & $85.20 \%$ \\
\hline & & 6-year undergraduate rate (Fall cohort) & $65.80 \%$ \\
\hline & & $\begin{array}{l}\% \text { of undergraduates with employment after } 3 \text { months of } \\
\text { graduation }\end{array}$ & $79 \%$ \\
\hline & & Undergraduate median salary & $\$ 47,250.00$ \\
\hline & & Graduate enrollment (Fall cohort) & 269 \\
\hline & & Graduate degrees awarded & 197 \\
\hline & & $\begin{array}{l}\% \text { of full time MBA with employment after } 3 \text { months of } \\
\text { graduation }\end{array}$ & $80 \%$ \\
\hline & & Full time MBA median salary & $\$ 54,500.00$ \\
\hline & & Learning support* & 4.53 \\
\hline & & Studying support* & 4.38 \\
\hline & & Innovation support* & 4.31 \\
\hline & \multirow{12}{*}{$\begin{array}{l}\text { Faculty } \\
\text { success }\end{array}$} & Student to faculty ratio & 38.52 \\
\hline & & Teaching quality (survey scale with 1-lowest to 5-highest) & 4.18 \\
\hline & & Teaching Awards \& Recognitions & 8 \\
\hline & & Prominent Journal Publications & 33 \\
\hline & & Research Grants Submitted & 23 \\
\hline & & Research Grants Funded & 8 \\
\hline & & Research Grants Expenditures & $\$ 1,412,853.00$ \\
\hline & & Research Awards \& Recognitions & 20 \\
\hline & & National \& international leadership & 35 \\
\hline & & Editorship & 60 \\
\hline & & Focused work support* & 4.47 \\
\hline & & Innovation support* & 4.2 \\
\hline & \multirow{4}{*}{$\begin{array}{l}\text { Staff } \\
\text { success }\end{array}$} & Staff to faculty ratio & 0.7 \\
\hline & & Staff Awards & 2 \\
\hline & & Focused work support* & 3.92 \\
\hline & & Innovation support* & 4.46 \\
\hline
\end{tabular}

*Survey Scale, 5 = Strongly Agree, 1 = Strongly Disagree 
TABLE 8. Student success comparisons.

\begin{tabular}{|l|l|l|l|}
\hline Student success sub-indicator & $\mathbf{2 0 1 6 - 2 0 1 7}$ & $\mathbf{2 0 1 7 - 2 0 1 8}$ & $\%$ change \\
\hline Undergraduate enrollment (Fall cohort) & 3263 & 3540 & $8 \%$ \\
\hline Undergraduate degrees awarded & 744 & 1086 & $46 \%$ \\
\hline $\begin{array}{l}\text { First to second year undergraduate retention rate (Fall } \\
\text { cohort) }\end{array}$ & $85.20 \%$ & $86.6 \%$ & $2 \%$ \\
\hline $\begin{array}{l}\text { 6-year undergraduate graduation rate (Fall cohort) } \\
\text { \% of undergraduates with employment after 3 months of } \\
\text { graduation }\end{array}$ & $79 \% .80 \%$ & $70.3 \%$ & $7 \%$ \\
\hline Undergraduate median salary & $\$ 47,250.00$ & $\$ 497,500.00$ & $1 \%$ \\
\hline Graduate enrollment (Fall cohort) & 269 & 334 & $24 \%$ \\
\hline Graduate degrees awarded & 197 & 219 & $11 \%$ \\
\hline $\begin{array}{l}\% \text { of full time MBA with employment after 3 months of } \\
\text { graduation }\end{array}$ & $80 \%$ & $84.00 \%$ & $5 \%$ \\
\hline Full time MBA median salary & $\$ 54,500.00$ & $\$ 55,000.00$ & $1 \%$ \\
\hline
\end{tabular}

research awards and recognition, editorship, focused work support, and innovation support. The staff success indicator has 4 sub-indicators: staff to faculty ratio, staff awards, focused work support, and innovation support.

Table 8 shows the results of comparing the quantitative measures of student success subindicators in two consecutive academic years. Except for the percentage of "undergraduates with employment after three months of graduation," which remains unchanged, all the subindicators of student success are showing a positive improvement. In particular, we see a double-digit percentage increase for "undergraduate degree awarded" and "graduate enrollment." The results provide evidence of the Gatton building's triple bottom line impact on students' academic success.

At the conclusion of this study, the environmental, social, and economic research methods were compiled to create a toolkit enabling analyses of other campus buildings at the University of Kentucky. For analyses at different institutions, the instruments that measure building performance would need to be acquired, but the methods and models from this study could be replicated. By integrating multidisciplinary perspectives into the toolkit, the research represents a more thorough account of sustainability in architecture and design.

\section{CONCLUSIONS}

This study contributes to both theory and practice of sustainable built environment research. Theoretically, it expands the definition and evaluation of sustainability geared specifically toward academic success. Practically, the study demonstrates the usefulness of a toolkit to collect data 
that illustrates its triple bottom line impacts on academic success. The resulting metrics serve as a baseline for benchmarking comparative and longitudinal studies in the future (Presley and Meade, 2010). Together, the study contributes to moving the vision of a sustainable campus for academic success from ideas to reality.

By engaging other disciplines besides architecture and design (i.e., economics, business, and statistics) in the research, the study benefited from the diversity of perspectives and processes in a cross-disciplinary problem-based approach. The methodology drew from the expertise of each area of study, which also facilitated participatory research in the classroom (Blair-Early, 2010). Leveraging the multi-disciplinarity of the study increased its visibility and ultimately increased the impact to the university community at large.

In resolving the question raised by the analogy of the blind man and his stick, Bateson concludes, "The way to delineate the system is to draw the limiting line in such a way that you do not cut any of these pathways in ways which leave things inexplicable." (Bateson, 1972, pp.459). Such are the shortcomings of many analyses that seek to understand the manifold impacts of architecture. This paper seeks to expand the system boundaries of what constitutes the measurement of sustainability in design to include multidisciplinary methods that examine social, environmental, and economic effects. In doing so, it attempts to preserve the connections between pathways that typically fall outside the scope of sustainability research in design.

In sum, the argument consists of three parts. First, sustainable design research must be multidisciplinary. With a growing body of knowledge that documents the widespread effects of architecture, in both tangible and intangible ways, understanding sustainability requires that research proceed along multidisciplinary pathways. Second, sustainable design research must employ a broad spectrum of technologies. These technologies include both hardware and software that generate both qualitative and quantitative data. Third, sustainable design research must be conceived as a sustainable process itself. By educating students in the methods by which sustainable design research is conducted, the potential impact grows alongside possibilities for future multidisciplinary collaborations. Using these arguments as guides for further research, the pursuit of sustainability might become one in which the gap between current practices and the pressing demands for more responsible design draws closer.

\section{REFERENCES}

Alexander, C. (1965). "A City Is Not a Tree," The Architectural Forum, Vol. 122, No. 1, pp. 58.

Bateson G. (1972). Steps to an Ecology of Mind, Ballantine Books, New York, NY.

Blair-Early, A. (2010). "Beyond Borders: Participatory Design Research and the Changing Role of Design," Visible Language, Vol. 44, No. 2, pp. 207-218.

Brandt P., Ernst, A., Gralla, F., Luederitz, C., Lang, D., Newig, J., Reinert, F., Abson, D. and von Wehrden, H. (2013) “A Review of Transdisciplinary Research in Sustainability Science,” Ecological Economics, Vol. 92, pp. $1-15$.

Gonchar, J. (2015). “The Picture of Health,” Architectural Record, Vol. 203, No. 6, pp. 140.

Center for the Built Environment (CBE), (2018). "Occupant Indoor Environmental Quality (IEQ) Survey," available at: http://www.cbe.berkeley.edu/research/survey.htm

Coates, J. (2003). Ecology and Social Work: Toward a New Paradigm, Fernwood Publishing, Halifax, Manitoba.

Denzer, A., and Hedges, K. (2011). “The Limitations of LEED: A Case Study,” Journal of Green Building, Vol. 6, No. 1, pp. 25-33.

Dillard, J., Dujon, V., and King, M. (2009). Understanding the Social Dimension of Sustainability, Routledge, New York, NY, pp. 1-12. 
International WELL Building Institute (IWBI), (2018). "Post-Occupancy Surveys," available at: http://standard. wellcertified.com/mind/post-occupancy-surveys

Peterson, R. (1994). "A Meta-Analysis of Cronbach's Coefficient Alpha," Journal of Consumer Research, Vol. 21, No. 2, pp. 381-391.

Presley, A., and Meade, L. (2010). "Benchmarking for Sustainability: An Application to the Sustainable Construction Industry," Benchmarking: An International Journal, Vol.17, No. 3 pp. 435-451.

Rupp, R.F., Vásquez, N.G., and Lamberts, R. (2015). "A Review of Human Thermal Comfort in the Built Environment," Energy and Buildings, Vol. 105, pp. 178-205.

Sanders, N. and Wood, J. (2015). Foundations of Sustainable Business, John Wiley \& Sons, Hoboken, NJ, pp. 16.

Simonen, K., Rodriguez, B., and De Wolf, C. (2017). "Benchmarking the Embodied Carbon of Buildings," Technology Architecture and Design, Vol. 1, No. 2, pp. 208-218.

Slaper, T. and Hall, T. (2011). “The Triple Bottom Line: What is it and How does it Work?” Indiana Business Review, Vol. 86, No. 1, pp. 4-8.

Western Australian Council of Social Service (WACOSS), (2000). "Model of Social Sustainability," available at: http://www.wacoss.org.au

\section{APPENDIX}

Please indicate how often you visit each of the following areas in the Gatton building.

\begin{tabular}{|c|c|c|c|c|c|c|c|}
\hline & Never & $\begin{array}{l}\text { Once a } \\
\text { Semester }\end{array}$ & $\begin{array}{l}\text { Once a } \\
\text { Month }\end{array}$ & $\begin{array}{l}\text { Once a } \\
\text { Week }\end{array}$ & $\begin{array}{l}\text { Once } \\
\text { a Day }\end{array}$ & $\begin{array}{c}\text { Multiple } \\
\text { Times } \\
\text { per } \\
\text { Week }\end{array}$ & $\begin{array}{c}\text { Multiple } \\
\text { Times } \\
\text { per Day }\end{array}$ \\
\hline Classroom & 0 & 0 & 0 & 0 & 0 & 0 & 0 \\
\hline Study room & 0 & 0 & 0 & 0 & 0 & 0 & 0 \\
\hline Conference room & 0 & 0 & 0 & 0 & 0 & 0 & 0 \\
\hline Faculty office & 0 & 0 & 0 & 0 & 0 & 0 & 0 \\
\hline Auditorium & 0 & 0 & 0 & 0 & 0 & 0 & 0 \\
\hline $\begin{array}{l}\text { Collaborative } \\
\text { study/breakout } \\
\text { rooms }\end{array}$ & 0 & 0 & 0 & 0 & 0 & 0 & 0 \\
\hline Behavioral lab. & 0 & 0 & 0 & 0 & 0 & 0 & 0 \\
\hline $\begin{array}{l}\text { Finance learning } \\
\text { center }\end{array}$ & 0 & 0 & 0 & 0 & 0 & O & O \\
\hline UK venture studio & 0 & 0 & 0 & 0 & 0 & 0 & 0 \\
\hline Quiet study area & 0 & 0 & 0 & 0 & 0 & 0 & 0 \\
\hline Lounge & O & 0 & O & 0 & 0 & 0 & 0 \\
\hline Atrium step area & O & O & 0 & 0 & 0 & 0 & 0 \\
\hline Cafe & 0 & 0 & 0 & 0 & 0 & 0 & 0 \\
\hline Outside plaza & 0 & 0 & 0 & 0 & 0 & 0 & 0 \\
\hline
\end{tabular}


Please indicate to what extent you agree with the following statements.

\begin{tabular}{|l|c|c|c|c|c|}
\cline { 2 - 6 } \multicolumn{1}{l|}{} & $\begin{array}{c}\text { Strongly } \\
\text { agree }\end{array}$ & $\begin{array}{c}\text { Somewhat } \\
\text { agree }\end{array}$ & $\begin{array}{c}\text { Neither } \\
\text { agree nor } \\
\text { disagree }\end{array}$ & $\begin{array}{c}\text { Somewhat } \\
\text { disagree }\end{array}$ & $\begin{array}{c}\text { Strongly } \\
\text { disagree }\end{array}$ \\
\hline $\begin{array}{l}\text { The temperature of the } \\
\text { building meets my comfort } \\
\text { level. }\end{array}$ & 0 & 0 & 0 & 0 & 0 \\
\hline $\begin{array}{l}\text { The lighting of the building is } \\
\text { appropriate for my activities. }\end{array}$ & 0 & 0 & 0 & 0 & 0 \\
\hline $\begin{array}{l}\text { The noise level of the building } \\
\text { is optimal during my stay. }\end{array}$ & 0 & 0 & 0 & 0 & 0 \\
\hline $\begin{array}{l}\text { The air quality of the building } \\
\text { meets my expectations. }\end{array}$ & 0 & 0 & 0 & 0 & 0 \\
\hline $\begin{array}{l}\text { The humidity in the building } \\
\text { meets my comfort level. }\end{array}$ & 0 & 0 & 0 & 0 & 0 \\
\hline $\begin{array}{l}\text { The furniture meets my } \\
\text { comfort level. }\end{array}$ & 0 & 0 & 0 & 0 & 0 \\
\hline $\begin{array}{l}\text { The furniture is arranged in } \\
\text { a manner that addresses my } \\
\text { needs. }\end{array}$ & 0 & 0 & 0 & 0 & 0 \\
\hline $\begin{array}{l}\text { There is enough seating in the } \\
\text { spaces where I need it. }\end{array}$ & 0 & 0 & 0 & 0 & 0 \\
\hline $\begin{array}{l}\text { The layout of the building } \\
\text { meets my need. }\end{array}$ & 0 & 0 & 0 & 0 & 0 \\
\hline $\begin{array}{l}\text { The opening hours of the } \\
\text { building meet my needs. }\end{array}$ & 0 & 0 & 0 & 0 & 0 \\
\hline
\end{tabular}

Please indicate to what extent you agree with the following statements.

\begin{tabular}{|l|c|c|c|c|c|}
\cline { 2 - 6 } \multicolumn{1}{l|}{} & $\begin{array}{c}\text { Strongly } \\
\text { agree }\end{array}$ & $\begin{array}{c}\text { Somewhat } \\
\text { agree }\end{array}$ & $\begin{array}{c}\text { Neither } \\
\text { agree nor } \\
\text { disagree }\end{array}$ & $\begin{array}{c}\text { Somewhat } \\
\text { disagree }\end{array}$ & $\begin{array}{c}\text { Strongly } \\
\text { disagree }\end{array}$ \\
\hline The facility supports studying. & 0 & 0 & 0 & 0 & 0 \\
\hline The facility supports learning. & 0 & 0 & 0 & 0 & 0 \\
\hline $\begin{array}{l}\text { The facility supports } \\
\text { innovation. }\end{array}$ & 0 & 0 & 0 & 0 & 0 \\
\hline $\begin{array}{l}\text { The facility supports } \\
\text { socialization. }\end{array}$ & 0 & 0 & 0 & 0 & 0 \\
\hline $\begin{array}{l}\text { The facility supports a sense of } \\
\text { community. }\end{array}$ & 0 & 0 & 0 & 0 & 0 \\
\hline $\begin{array}{l}\text { The facility supports } \\
\text { collaborative work. }\end{array}$ & 0 & 0 & 0 & 0 & 0 \\
\hline $\begin{array}{l}\text { The facility supports } \\
\text { relaxation. }\end{array}$ & 0 & 0 & 0 & 0 & 0 \\
\hline
\end{tabular}

